\title{
Influence of Flue Gas Desulfurization Gypsum on Phosphorus Loss from a Horticultural Growth Medium
}

\author{
Dexter Brown Watts *, George Brett Runion and Henry Allen Torbert
}

Citation: Watts, D.B.; Runion, G.B.; Torbert, H.A. Influence of Flue Gas Desulfurization Gypsum on

Phosphorus Loss from a Horticultural Growth Medium. Horticulturae 2021, 7, 199. https://doi.org/10.3390/ horticulturae7070199

Received: 21 June 2021

Accepted: 15 July 2021

Published: 17 July 2021

Publisher's Note: MDPI stays neutral with regard to jurisdictional claims in published maps and institutional affiliations.

Copyright: (c) 2021 by the authors. Licensee MDPI, Basel, Switzerland. This article is an open access article distributed under the terms and conditions of the Creative Commons Attribution (CC BY) license (https:// creativecommons.org/licenses/by/ $4.0 /)$.
USDA-ARS National Soil Dynamics Laboratory, Auburn, AL 36832, USA; Brett.Runion@usda.gov (G.B.R.); Allen.Torbert@usda.gov (H.A.T.)

* Correspondence: Dexter.Watts@usda.gov

\begin{abstract}
In response to agriculture's contribution to surface water quality, considerable effort is being made to develop best management practices to reduce nutrient loss. To evaluate the efficacy of gypsum as a horticultural media amendment for controlling phosphorus (P) leaching, flue gas desulfurization (FGD) gypsum was added to a standard horticultural growth medium at 0, 2.5, 5, 10 or $15 \%(v / v)$. FGD gypsum was either mixed with the growing medium or placed at the bottom of the containers. A fast-release or a control-release fertilizer was top-dressed to containers. The greatest $P$ leaching occurred with the fertilizer-only treatments (no gypsum). Dissolved reactive P (DRP) losses were highest on the initial day of measurement for the fast-release fertilizer and then decreased rapidly. There was a delayed release of DRP from the controlled-release fertilizer. Increasing rates of FGD gypsum addition resulted in decreasing DRP leaching concentration loss and load. The FGD gypsum decreased leachate DRP concentration loss by a maximum of $75 \%$, with an average decrease of $46 \%$. Mixing the FGD gypsum with the medium (an easier/less expensive means of incorporation) was most effective with the fast-release fertilizer. These preliminary results indicate that less gypsum may be needed to reduce $P$ loss from fast-released fertilizer as opposed to control-release fertilizer. FGD gypsum remained effective in reducing DRP loss throughout the experiment.
\end{abstract}

Keywords: flue gas desulfurization gypsum; dissolved reactive phosphorus; nutrient leaching

\section{Introduction}

Eutrophication has degraded freshwater systems in the US by reducing water quality and altering ecosystem structure and function [1]. Increased nitrogen (N) and phosphorus (P) loadings via discharge emanating from diffuse agricultural sources to surface waters have been implicated as the major underlying cause of accelerated eutrophication. This has disrupted the functional continuum of aquatic ecosystems by causing diminished water clarity, harmful and nuisance algal blooms, oxygen-deficient/hypoxic zones, and degradation of habitats important for living resources [1-7]. Consequently, addressing nutrient losses derived from agriculture has become a challenging issue because $\mathrm{N}$ and $\mathrm{P}$ fertilization is crucial to optimize crop production.

The greenhouse and nursery industry in the U.S. is a major sector of agriculture, with farm-level sales of approximately $\$ 13.8$ billion in 2019 [8]. It is known that the horticultural industry is a significant contributor of nutrient loading to surface and ground water [9-11]. This risk is particularly high for horticultural crops produced in containers. For example, to sufficiently produce nursey crops in a containerized production system, the application of large quantities of nutrients and water is required [12]. Containerized soilless media have low nitrate and phosphate sorption capacities and high hydraulic conductivity, subjecting them to extensive leaching [13]. In addition, these nutrients are often applied in excess of plant requirements and may be lost from the system by leaching or runoff before plants can utilize them for crop production $[12,14,15]$. Furthermore, horticultural production facilities often produce multiple crops in a year, exacerbating the potential threat of environmental 
degradation from nutrient loss [12]. Thus, there is a need for adaptive management practices that mitigate $\mathrm{N}$ and $\mathrm{P}$ loss from containerized production systems.

Research in recent decades has shown that flue gas desulfurization (FGD) gypsum can effectively reduce $P$ loss from agricultural fields [16-21]. As a result, corollary interest in the use of FGD gypsum and its attendant response to $P$ reduction have increased in recent years for row crops and forage production systems [22]. Furthermore, some state extension systems have adopted gypsum as a nutrient best management practice $[23,24]$. Some states have included gypsum into their USDA-NRCS 590 Nutrient Management Standards (P-Index) [25], and nationally, gypsum use has been adopted as a USDA-NRCS Conservation Practice standard (CPS 333) [26]. However, this encouraged adoption of FGD gypsum to abate P loss has primarily targeted crop production systems occurring on agricultural land.

Despite increased interest in the use of gypsum for agriculture, no study to our knowledge has documented and confirmed the effectiveness of FGD gypsum to mitigate $\mathrm{P}$ loss from container nursery production systems. It is believed that dissolved reactive $\mathrm{P}$ (DRP) loss would be greatly reduced from nursery containers by adding FGD gypsum to the soilless media. Research is needed to evaluate the impact adding FGD gypsum has on nutrient retention from soilless container media. Therefore, the objective of this study was to investigate P loss from nursery containers amended with FGD gypsum using two application methods; mixed vs. layered. It is our belief that integrating FGD gypsum into containerized production systems may become an exemplar best management practice for mitigating $\mathrm{P}$ loss from nurseries as it has with other agricultural systems.

\section{Materials and Methods}

A nursey container leaching study was conducted for nine weeks from June to August 2019 in an enclosed facility located at the USDA-Agricultural Research Service's National Soil Dynamics Laboratory to evaluate the efficacy of using FGD gypsum to reduce P loss from a horticulture potting medium. Pro-Mix BX General Purpose (Premier Horticulture, Inc., Quakertown, PA, USA) growing medium composed of $75 \%$ to $85 \%$ Canadian peatmoss, perlite, vermiculite, and dolomitic and calcitic limestone was used for this study. The experimental units consisted of plastic $8 \mathrm{~L}$ Gro Pro black square containers (Sunlight Supply, Inc., Vancouver, WA, USA) that were $24 \mathrm{~cm}$ tall, measuring 23 by $23 \mathrm{~cm}$ at the top, and tapering to 18 by $18 \mathrm{~cm}$ at the base. A piece of cheesecloth was placed at the base of each container to minimize media loss. FGD gypsum, collected from a local coal-fired electrical utility plant ( $\mathrm{pH} 7$; moisture $~ 14 \%$; fine powder) was either mixed with the growing medium or placed at the bottom of the containers. The media substrate was amended with $0,2.5,5,10$ or $15 \%$ FGD gypsum $(v / v)$. Quantities of FGD gypsum supplied were determined by first establishing the weight of medium needed and then weighing the appropriate amount of FGD gypsum needed for the appropriated volumetric ratios.

This study also evaluated the influence of using FGD gypsum to reduce P loss in leachate between a controlled-release fertilizer system and a fast-release fertilizer delivery system. Osmocote ${ }^{\circledR}$ 14-14-14 (Scotts Company LLC, Marysville, OH, USA) was used as the controlled-release fertilizer source and a blend of urea (46-0-0), triple super phosphate $(0-46-0)$ and muriate of potash (0-0-60) was used as the fast-release fertilizer. Osmocote ${ }^{\circledR}$ 14-14-14 is commonly used in Alabama nursery productions because it can continuously release nutrients for 3 to 4 months. The controlled-release fertilizer was applied at the manufacturer's recommended rate per container for topdressed placement (58 $\mathrm{g}$ per container). The fast-release fertilizer blend was applied at the same N-P-K fertilizer rate as that of the controlled-release fertilizer. All treatments were maintained fallow (not containing a plant).

One day prior to initiating the leaching study, the containers were watered to saturation based on the average of four extra containers designated for this purpose $(\sim 2500 \mathrm{~mL}$ water added to each container). We estimated saturation by measuring the amount of water needed for containers to reach drip point (i.e., when water initially begins to drip from drain holes). Afterwards, the containers were leached daily for the first three weeks, 
except weekends. Additional water was added on Mondays following the weekend to compensate for leaching losses that may have occurred over the weekend. After week three, containers were leached weekly, adding the amount of water needed to compensate for the days in between leaching. To promote leaching, tap water was delivered by pouring $500 \mathrm{~mL}$ through a diffuser placed approximated $5 \mathrm{~cm}$ above the containers. The containers were then allowed to drain for $30 \mathrm{~min}$. Leachate water was collected in large trays $(\sim 61 \mathrm{~cm}$ by $\sim 41 \mathrm{~cm}$ ) placed under each container and the volume of water recorded to determine leachate load; there were a total of eight leachate collections in this study. Source water samples from each leaching event were also collected to determine background nutrient concentrations.

After leachate collection, the samples were centrifuged, vacuum filtered through a $0.45 \mu \mathrm{m}$ membrane, acidified with concentrated $\mathrm{HCl}$, and then stored at $4{ }^{\circ} \mathrm{C}$ until analysis. The filtered samples were analyzed for DRP using the Bran-Luebbe Autoanalyzer (Bran-Luebbe, Norderstedt, Germany). This method of determining DRP uses colorimetric procedures as described by Kovar and Pierzynski [27].

This study was conducted as a 2 (fertility sources-slow-release vs. controlled-release) X 4 (gypsum application rates-2.5, 5, 10, and $15 \% v / v$ ) X 2 (application methods-mixed vs. separated) factorial arrangement plus 2 fertilizer controls (controlled-release and fastrelease without gypsum) in a completely randomized design with 4 replications, totaling 72 experimental units. Statistical analyses for each response variable in this experiment were performed using analysis of variance (ANOVA) with the PROC Glimmix procedure of SAS 9.4 [28] to determine treatment effects. Fisher's protected LSD values were used to identify significant differences among treatments. A significance level of $p=0.05$ was established a priori, and differences between 0.05 and 0.10 were considered significant trends. Significant differences $(p=0.05)$ were observed among dates, between fertility source, and between gypsum application method, thus they were analyzed separately. Regression analysis was used to investigate the response of DRP concentration losses to increasing FGD gypsum application rates $(0,2.5,5,10$ and $15 \% v / v)$.

\section{Results and Discussion}

Significant reductions in DRP losses were observed in this study with the addition of gypsum. Visual differences among FGD gypsum treatment were observed, with higher rates having lighter color and increased clarity (Figure 1). Dissolved reactive P loss was significantly different between fertilizers (fast- vs. controlled-release), gypsum application method (mixed vs. bottom of container), and among days; thus, P concentrations losses and loading are presented separately by fertilizer, gypsum application method, and day.

DRP concentration losses were significantly affected by FGD gypsum on most sampling days. With fast-release fertilizer when gypsum was placed at the bottom of the media no differences were observed on day 171, 189, and 196 (Table 1). Further, no differences were observed for the controlled-release fertilizer when FGD gypsum was mixed on day 172 or when placed at the bottom of the container and on day 196 (Table 2). For the fastrelease fertilizer source, DRP losses were highest on the initial day of measurement and decreased rapidly over time, while there was a delayed release for DRP loss observed from the controlled-release fertilizer source. Others have also reported a delay in the release of $P$ from controlled-release fertilizer in nursey crop production research [29-32]. Fast-release fertilizers, which are commonly water soluble, typically release nutrients shortly after initial watering [33]. This makes nutrients readily available for either plant uptake or leaching $[34,35]$. Alternatively, controlled-release fertilizers are generally coated so that nutrient diffusion occurs over a longer period of time [36] allowing plant uptake to be more synchronized with fertilizer release. 


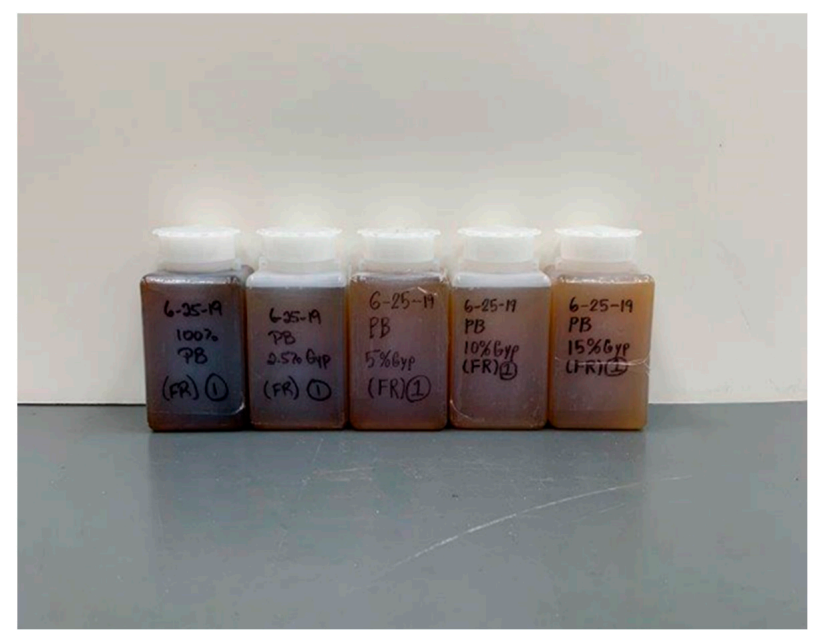

Figure 1. FGD gypsum treatment effects on clarity of leachate water after a leaching event.

Table 1. Temporal changes in dissolved P concentration leaching losses observed over time from containers in 2019 as affected by FGD gypsum mixed with medium or placed at the bottom of containers fertilized with a fast release fertilizer.

\begin{tabular}{|c|c|c|c|c|c|c|c|c|c|}
\hline \multirow{2}{*}{$\begin{array}{l}\text { Application } \\
\text { Method }\end{array}$} & \multirow{2}{*}{$\underset{\text { Rate }}{\text { Gypsum }}$} & \multicolumn{8}{|c|}{ Sampling Day of Year } \\
\hline & & 171 & 172 & 176 & 179 & 183 & 189 & 196 & 234 \\
\hline \multirow{7}{*}{ mixed } & & \multicolumn{8}{|c|}{ Inorganic $\mathrm{P}\left(\mathrm{mg} \mathrm{L}^{-1}\right)$} \\
\hline & 0 & $167.82 \mathrm{a}$ & $90.38 \mathrm{a}$ & $13.37 \mathrm{a}$ & $27.01 \mathrm{a}$ & $62.09 \mathrm{a}$ & $72.12 \mathrm{a}$ & $95.95 \mathrm{a}$ & $62.86 \mathrm{a}$ \\
\hline & 2.5 & $115.10 \mathrm{ab}$ & $80.62 \mathrm{a}$ & $4.88 \mathrm{~b}$ & $8.50 \mathrm{~b}$ & $17.19 \mathrm{~b}$ & $27.42 \mathrm{~b}$ & $29.76 \mathrm{~b}$ & $26.33 \mathrm{~b}$ \\
\hline & 5 & $108.18 \mathrm{ab}$ & $72.65 \mathrm{ab}$ & $3.82 \mathrm{~b}$ & $4.66 \mathrm{bc}$ & $13.42 \mathrm{~b}$ & $21.38 \mathrm{bc}$ & $29.21 b$ & $22.09 \mathrm{~b}$ \\
\hline & 10 & $95.79 \mathrm{~b}$ & $67.01 \mathrm{ab}$ & $3.21 \mathrm{~b}$ & $2.33 c$ & $9.84 \mathrm{~b}$ & $21.94 \mathrm{bc}$ & $25.83 \mathrm{~b}$ & $17.66 \mathrm{~b}$ \\
\hline & 15 & $62.98 \mathrm{~b}$ & $52.53 \mathrm{~b}$ & $2.91 \mathrm{~b}$ & $3.64 \mathrm{bc}$ & $9.30 \mathrm{~b}$ & $17.03 \mathrm{c}$ & $26.22 \mathrm{~b}$ & $5.17 \mathrm{c}$ \\
\hline & $p>F$ & 0.048 & 0.067 & 0.006 & $<0.001$ & $<0.001$ & $<0.001$ & $<0.001$ & $<0.001$ \\
\hline \multirow{6}{*}{ separated } & 0 & $167.82 \mathrm{a}$ & $90.38 \mathrm{a}$ & $13.37 \mathrm{a}$ & $27.01 \mathrm{a}$ & $62.09 \mathrm{a}$ & $72.12 \mathrm{a}$ & $95.95 \mathrm{a}$ & $62.86 \mathrm{a}$ \\
\hline & 2.5 & $145.80 \mathrm{a}$ & $82.86 \mathrm{a}$ & $8.18 \mathrm{ab}$ & $13.68 \mathrm{~b}$ & $50.38 \mathrm{~b}$ & $70.87 \mathrm{a}$ & $94.23 \mathrm{a}$ & $60.10 \mathrm{a}$ \\
\hline & 5 & $121.10 \mathrm{a}$ & $69.79 \mathrm{ab}$ & $4.18 \mathrm{bc}$ & $10.14 b c$ & $33.33 c$ & $69.72 \mathrm{a}$ & 93.78 a & $44.27 \mathrm{~b}$ \\
\hline & 10 & $103.99 \mathrm{a}$ & $55.42 \mathrm{~b}$ & $2.67 \mathrm{c}$ & $7.24 b c$ & $12.60 \mathrm{~d}$ & $56.43 \mathrm{a}$ & 79.64 a & $27.81 \mathrm{c}$ \\
\hline & 15 & $95.81 \mathrm{a}$ & $50.59 \mathrm{~b}$ & $1.17 \mathrm{c}$ & $5.63 \mathrm{c}$ & $12.01 \mathrm{~d}$ & $52.27 \mathrm{a}$ & $76.15 \mathrm{a}$ & $25.89 \mathrm{c}$ \\
\hline & $p>F$ & 0.269 & 0.016 & 0.001 & 0.001 & $<0.001$ & 0.171 & 0.365 & $<0.001$ \\
\hline
\end{tabular}

Values within the same column for a nutrient with common letters are significantly different at $p<0.05$ and are considered significant trends at $p<0.10$.

Table 2. Temporal changes in dissolved P concentration leaching losses observed over time from containers in 2019 as affected by FGD gypsum mixed with medium or placed at the bottom of containers fertilized with a controlled-released fertilizer.

\begin{tabular}{|c|c|c|c|c|c|c|c|c|c|}
\hline \multirow{2}{*}{$\begin{array}{l}\text { Application } \\
\text { Method }\end{array}$} & \multirow{2}{*}{$\begin{array}{c}\text { Gypsum } \\
\text { Rate }\end{array}$} & \multicolumn{8}{|c|}{ Sampling Day of Year } \\
\hline & & 171 & 172 & 176 & 179 & 183 & 189 & 196 & 234 \\
\hline \multirow{7}{*}{ mixed } & & \multicolumn{8}{|c|}{ Inorganic $\mathrm{P}\left(\mathrm{mg} \mathrm{L}^{-1}\right)$} \\
\hline & 0 & $105.13 \mathrm{a}$ & 96.96 a & $99.25 \mathrm{a}$ & $76.94 \mathrm{a}$ & $91.73 \mathrm{a}$ & 73.57 a & $66.43 \mathrm{a}$ & $58.54 \mathrm{a}$ \\
\hline & 2.5 & $98.81 \mathrm{a}$ & $86.94 \mathrm{a}$ & $67.30 \mathrm{~b}$ & $49.03 \mathrm{~b}$ & $76.70 \mathrm{a}$ & $60.63 \mathrm{~b}$ & $46.58 \mathrm{~b}$ & $40.21 \mathrm{~b}$ \\
\hline & 5 & $87.40 \mathrm{ab}$ & $80.64 \mathrm{a}$ & $62.57 \mathrm{~b}$ & $49.65 \mathrm{~b}$ & $48.84 \mathrm{~b}$ & $54.19 \mathrm{~b}$ & $42.03 \mathrm{~b}$ & $33.70 \mathrm{c}$ \\
\hline & 10 & $69.05 \mathrm{bc}$ & $67.22 \mathrm{a}$ & $46.61 \mathrm{c}$ & $36.77 \mathrm{bc}$ & $35.38 \mathrm{~b}$ & $34.87 \mathrm{c}$ & $34.59 c$ & $29.77 \mathrm{c}$ \\
\hline & 15 & $62.17 c$ & $63.85 \mathrm{a}$ & $38.14 \mathrm{c}$ & $22.65 \mathrm{c}$ & $13.42 \mathrm{c}$ & $23.78 \mathrm{~d}$ & $26.00 \mathrm{~d}$ & $30.86 \mathrm{c}$ \\
\hline & $p>F$ & $<0.001$ & 0.452 & $<0.001$ & 0.005 & $<0.001$ & $<0.001$ & $<0.001$ & $<0.001$ \\
\hline \multirow{6}{*}{ separated } & 0 & $105.13 \mathrm{a}$ & $96.96 \mathrm{a}$ & $99.25 \mathrm{a}$ & $76.94 \mathrm{a}$ & $91.73 \mathrm{a}$ & $73.57 \mathrm{a}$ & $66.43 \mathrm{a}$ & $58.54 \mathrm{a}$ \\
\hline & 2.5 & $82.66 \mathrm{ab}$ & $84.68 \mathrm{ab}$ & $55.24 \mathrm{~b}$ & $66.25 \mathrm{ab}$ & $47.02 \mathrm{~b}$ & $61.01 \mathrm{ab}$ & $62.07 \mathrm{a}$ & $41.82 \mathrm{~b}$ \\
\hline & 5 & $69.05 \mathrm{bc}$ & $72.65 \mathrm{ab}$ & $53.17 \mathrm{~b}$ & $55.15 \mathrm{~b}$ & $49.63 \mathrm{~b}$ & 58.46 bc & $55.36 \mathrm{a}$ & $37.21 b c$ \\
\hline & 10 & $58.35 \mathrm{bc}$ & $55.14 \mathrm{bc}$ & $19.13 \mathrm{c}$ & $40.33 \mathrm{c}$ & $41.39 \mathrm{~b}$ & $50.58 \mathrm{bc}$ & $56.00 \mathrm{a}$ & $27.45 \mathrm{c}$ \\
\hline & 15 & $55.53 c$ & $43.04 \mathrm{c}$ & $7.66 \mathrm{c}$ & $17.63 \mathrm{~d}$ & $36.06 \mathrm{~b}$ & $45.79 c$ & 54.77 a & $29.60 \mathrm{c}$ \\
\hline & $p>F$ & 0.007 & 0.022 & 0.001 & $<0.001$ & $<0.001$ & 0.013 & 0.568 & 0.001 \\
\hline
\end{tabular}

Values within the same column for a nutrient with common letters are significantly different at $p<0.05$ and are considered significant trends at $p<0.10$. 
During leaching events occurring shortly after treatment application, DRP concentrations losses ranged from 168 to $56 \mathrm{mg} \mathrm{L}^{-1}$, where the maximum was observed for the fast-release fertilizer-only control treatment. DRP concentration loss from the fertilizer-only control treatment was consistently highest for each leaching event. A favorable response was observed for the use of FGD gypsum as an amendment in the potting medium, substantially reducing DRP losses to leaching for both fast-release (Table 1) and controlled-release (Table 2) fertilizer. Most FGD gypsum additions decreased DRP loss, with losses tending to be lower as gypsum rates increased.

Overall, mixing gypsum into the medium lowered $(p<0.001)$ DRP loss $\left(48.6 \mathrm{mg} \mathrm{L}^{-1}\right)$ compared to having a separate layer at the bottom of the container $\left(56.1 \mathrm{mg} \mathrm{L}^{-1}\right)$; analysis showed that this was true only for the fast-release fertilizer $(57.2=56.4=55.7>40.0$, for mixed controlled-release, separated controlled-release, separated fast-release, and mixed fast-release treatments, respectively). Adding FGD gypsum to the containers decreased leachate DRP loss by a maximum $75 \%$, with an average decrease of $46 \%$. In general, as the amount of FGD gypsum increased, DRP loss decreased. Reductions in P loss could be a result of gypsum reacting with soluble $\mathrm{P}$ to form insoluble Ca-P complexes [37], such as hydroxyapatite and fluorapatite [38]. Shreckhise et al. [39] evaluate the influence of using dolomite on the reduction in P loss from nursey containers. Similar to our results, they observed reduction in P loss to leaching with the addition of dolomite when compared to fertilized substrate with no amendments. Previous research has also shown that gypsum can reduce DRP losses from agricultural fields receiving poultry litter [17-20,40], poultry lagoon effluent [16], or from soils high in P [41]. This is the first work we are aware of showing reductions in P loss from horticultural container systems following gypsum addition.

It is also important to note that the findings from this study show the effectiveness of using FGD gypsum to reduce DRP loss observed at the beginning as well as at the end of this study, indicating that not all of the FGD gypsum applied had dissolved. Results from this study indicate that reducing P loss with FGD gypsum was effective over the 9 -week experiment period. This shows that FGD gypsum may be used as a tool to reduce $P$ loss from horticultural containers and suggests that growers could potentially reduce total loading of nutrients in runoff by adding FGD gypsum to their potting media. This could have great benefits in areas with strict water quality requirements or where environmental quality is a concern.

Phosphorus loading data (mg), a product of leachate volume and nutrient concentration, generally followed similar treatment patterns (regarding fertilizer type and application method) as were observed for $P$ concentration data (Tables 3 and 4). This is a result of the FGD gypsum not having a major nor consistent effect on leachate volume.

When averaged across all dates, mixing FGD gypsum with the fast-release fertilizer was very effective at reducing $P$ loss at all rates (Figure 2). In contrast, placing the FGD gypsum in a separate layer at the bottom of the container showed lower P loss from the fast-release fertilizer. Further, increasing rates of FGD gypsum showed more stepwise reductions in $\mathrm{P}$ loss. When included with the controlled-release fertilizer, response of $\mathrm{P}$ loss to FGD gypsum rates showed similar stepwise patterns for both mixed and layered treatments (Figure 3). Linear regression analyses showed similar significant $(p \leq 0.002)$ responses to the FGD gypsum rate for all combinations of fertilizer type and placement. However, the controlled-release fertilizer showed a better linear fit to the data as evidenced by higher $\mathrm{r} 2$ values $(0.361,0.380,0.120$, and 0.080 for mixed controlled-release, separated controlled-release, mixed fast-released, and separated fast-release treatments, respectively). As was mentioned for Tables 3 and 4, averaged P loading showed patterns similar to $\mathrm{P}$ concentration (Figures 4 and 5). 
Table 3. Temporal changes in dissolved P leaching load observed over time from containers in 2019 as affected by FGD gypsum mixed with medium or placed at the bottom of containers fertilized with a fast release fertilizer.

\begin{tabular}{cccccccccc}
\hline $\begin{array}{c}\text { Application } \\
\text { Method }\end{array}$ & $\begin{array}{c}\text { Gypsum } \\
\text { Rate }\end{array}$ & $\mathbf{1 7 1}$ & $\mathbf{1 7 2}$ & $\mathbf{1 7 6}$ & $\mathbf{1 7 9}$ & $\mathbf{1 8 3}$ & $\mathbf{1 8 9}$ & $\mathbf{1 9 6}$ & $\mathbf{2 3 4}$ \\
\hline & & & & & Inorganic P Load $(\mathrm{mg})$ & \\
& 0 & $62.26 \mathrm{a}$ & $23.55 \mathrm{a}$ & $3.35 \mathrm{a}$ & $7.23 \mathrm{a}$ & $16.41 \mathrm{a}$ & $33.56 \mathrm{a}$ & $42.17 \mathrm{a}$ & $19.31 \mathrm{a}$ \\
& 2.5 & $38.57 \mathrm{~b}$ & $24.29 \mathrm{a}$ & $1.57 \mathrm{~b}$ & $2.84 \mathrm{~b}$ & $5.91 \mathrm{~b}$ & $12.91 \mathrm{~b}$ & $13.83 \mathrm{~b}$ & $8.94 \mathrm{~b}$ \\
mixed & 5 & $36.27 \mathrm{~b}$ & $22.15 \mathrm{a}$ & $1.15 \mathrm{~b}$ & $1.49 \mathrm{bc}$ & $3.01 \mathrm{bc}$ & $10.33 \mathrm{bc}$ & $13.17 \mathrm{~b}$ & $7.16 \mathrm{~b}$ \\
& 10 & $40.56 \mathrm{ab}$ & $21.11 \mathrm{a}$ & $1.11 \mathrm{~b}$ & $0.83 \mathrm{c}$ & $3.59 \mathrm{bc}$ & $10.67 \mathrm{~b}$ & $12.09 \mathrm{~b}$ & $6.04 \mathrm{~b}$ \\
& 15 & $27.15 \mathrm{~b}$ & $18.55 \mathrm{a}$ & $1.00 \mathrm{~b}$ & $1.28 \mathrm{bc}$ & $5.97 \mathrm{c}$ & $8.07 \mathrm{c}$ & $11.84 \mathrm{~b}$ & $1.56 \mathrm{c}$ \\
& & 0.056 & 0.669 & 0.022 & $<0.001$ & $<0.001$ & $<0.001$ & $<0.001$ & $<0.001$ \\
\hline & 0 & $62.26 \mathrm{a}$ & $23.55 \mathrm{a}$ & $3.35 \mathrm{a}$ & $7.23 \mathrm{a}$ & $16.41 \mathrm{a}$ & $33.56 \mathrm{a}$ & $42.17 \mathrm{a}$ & $19.31 \mathrm{a}$ \\
& 2.5 & $49.24 \mathrm{a}$ & $23.29 \mathrm{a}$ & $2.69 \mathrm{a}$ & $4.48 \mathrm{~b}$ & $16.70 \mathrm{a}$ & $33.19 \mathrm{a}$ & $41.42 \mathrm{ab}$ & $19.89 \mathrm{a}$ \\
& 5 & $39.73 \mathrm{a}$ & $19.52 \mathrm{ab}$ & $1.28 \mathrm{~b}$ & $3.11 \mathrm{~b}$ & $10.07 \mathrm{~b}$ & $32.06 \mathrm{ab}$ & $39.32 \mathrm{ab}$ & $13.17 \mathrm{~b}$ \\
& 10 & $41.24 \mathrm{a}$ & $17.20 \mathrm{ab}$ & $0.84 \mathrm{~b}$ & $2.25 \mathrm{~b}$ & $3.97 \mathrm{c}$ & $25.23 \mathrm{ab}$ & $31.04 \mathrm{bc}$ & $7.48 \mathrm{c}$ \\
& 15 & $37.28 \mathrm{a}$ & $15.85 \mathrm{~b}$ & $0.39 \mathrm{~b}$ & $1.84 \mathrm{~b}$ & $3.67 \mathrm{c}$ & $23.06 \mathrm{~b}$ & $28.31 \mathrm{c}$ & $6.62 \mathrm{c}$ \\
& $p>F$ & 0.302 & 0.111 & 0.002 & 0.004 & $<0.001$ & 0.090 & 0.049 & $<0.001$ \\
\hline
\end{tabular}

Values within the same column for a nutrient with common letters are significantly different at $p<0.05$ and are considered significant trends at $p<0.10$.

Table 4. Temporal changes in dissolved P leaching load observed over time from containers in 2019 as affected by FGD gypsum mixed with medium or placed at the bottom of containers fertilized with a controlled-released fertilizer.

\begin{tabular}{cccccccccc}
\hline $\begin{array}{c}\text { Application } \\
\text { Method }\end{array}$ & $\begin{array}{c}\text { Gypsum } \\
\text { Rate }\end{array}$ & $\mathbf{1 7 1}$ & $\mathbf{1 7 2}$ & $\mathbf{1 7 6}$ & $\mathbf{1 7 9}$ & $\mathbf{1 8 3}$ & $\mathbf{1 8 9}$ & $\mathbf{1 9 6}$ & $\mathbf{2 3 4}$ \\
\hline & & & & & \multicolumn{2}{c}{ Snorganic P Load $(\mathrm{mg})$} \\
& 0 & $36.90 \mathrm{a}$ & $26.12 \mathrm{a}$ & $28.03 \mathrm{a}$ & $21.54 \mathrm{a}$ & $25.94 \mathrm{a}$ & $33.24 \mathrm{a}$ & $27.93 \mathrm{a}$ & $17.93 \mathrm{a}$ \\
& 2.5 & $28.82 \mathrm{ab}$ & $25.12 \mathrm{a}$ & $22.87 \mathrm{ab}$ & $16.43 \mathrm{ab}$ & $26.72 \mathrm{a}$ & $28.31 \mathrm{~b}$ & $21.15 \mathrm{~b}$ & $14.03 \mathrm{~b}$ \\
mixed & 5 & $27.11 \mathrm{ab}$ & $23.42 \mathrm{a}$ & $20.58 \mathrm{bc}$ & $16.38 \mathrm{ab}$ & $16.57 \mathrm{~b}$ & $25.53 \mathrm{~b}$ & $19.04 \mathrm{~b}$ & $10.91 \mathrm{c}$ \\
& 10 & $25.02 \mathrm{~b}$ & $21.26 \mathrm{a}$ & $15.65 \mathrm{~cd}$ & $13.14 \mathrm{ab}$ & $13.07 \mathrm{~b}$ & $17.00 \mathrm{c}$ & $16.06 \mathrm{c}$ & $9.69 \mathrm{~cd}$ \\
& 15 & $23.41 \mathrm{~b}$ & $21.50 \mathrm{a}$ & $13.24 \mathrm{~d}$ & $8.07 \mathrm{~b}$ & $4.69 \mathrm{c}$ & $11.54 \mathrm{~d}$ & $11.85 \mathrm{~d}$ & $8.87 \mathrm{~d}$ \\
& $p$ & 0.086 & 0.884 & 0.001 & 0.069 & $<0.001$ & $<0.001$ & $<0.001$ & $<0.001$ \\
\hline & 0 & $36.90 \mathrm{a}$ & $26.12 \mathrm{a}$ & $28.03 \mathrm{a}$ & $21.54 \mathrm{ab}$ & $25.94 \mathrm{a}$ & $33.24 \mathrm{a}$ & $27.93 \mathrm{a}$ & $17.93 \mathrm{a}$ \\
& 2.5 & $25.90 \mathrm{~b}$ & $23.67 \mathrm{a}$ & $20.06 \mathrm{~b}$ & $22.76 \mathrm{a}$ & $16.09 \mathrm{~b}$ & $29.29 \mathrm{ab}$ & $28.24 \mathrm{a}$ & $15.11 \mathrm{ab}$ \\
& 5 & $20.55 \mathrm{~b}$ & $21.63 \mathrm{ab}$ & $17.88 \mathrm{~b}$ & $16.97 \mathrm{~b}$ & $16.26 \mathrm{~b}$ & $26.89 \mathrm{abc}$ & $23.48 \mathrm{a}$ & $12.67 \mathrm{~b}$ \\
& 10 & $21.59 \mathrm{~b}$ & $17.64 \mathrm{ab}$ & $6.13 \mathrm{c}$ & $12.11 \mathrm{c}$ & $12.19 \mathrm{bc}$ & $22.75 \mathrm{bc}$ & $22.32 \mathrm{a}$ & $7.92 \mathrm{c}$ \\
& 15 & $22.38 \mathrm{~b}$ & $13.74 \mathrm{~b}$ & $2.41 \mathrm{c}$ & $4.99 \mathrm{~d}$ & $9.83 \mathrm{c}$ & $20.79 \mathrm{c}$ & $21.37 \mathrm{a}$ & $8.38 \mathrm{c}$ \\
& $p>F$ & 0.011 & 0.103 & $<0.001$ & $<0.001$ & $<0.001$ & 0.013 & 0.258 & $<0.001$ \\
\hline
\end{tabular}

Values within the same column for a nutrient with common letters are significantly different at $p<0.05$ and are considered significant trends at $p<0.10$. 
Fast-Release Fertilizer

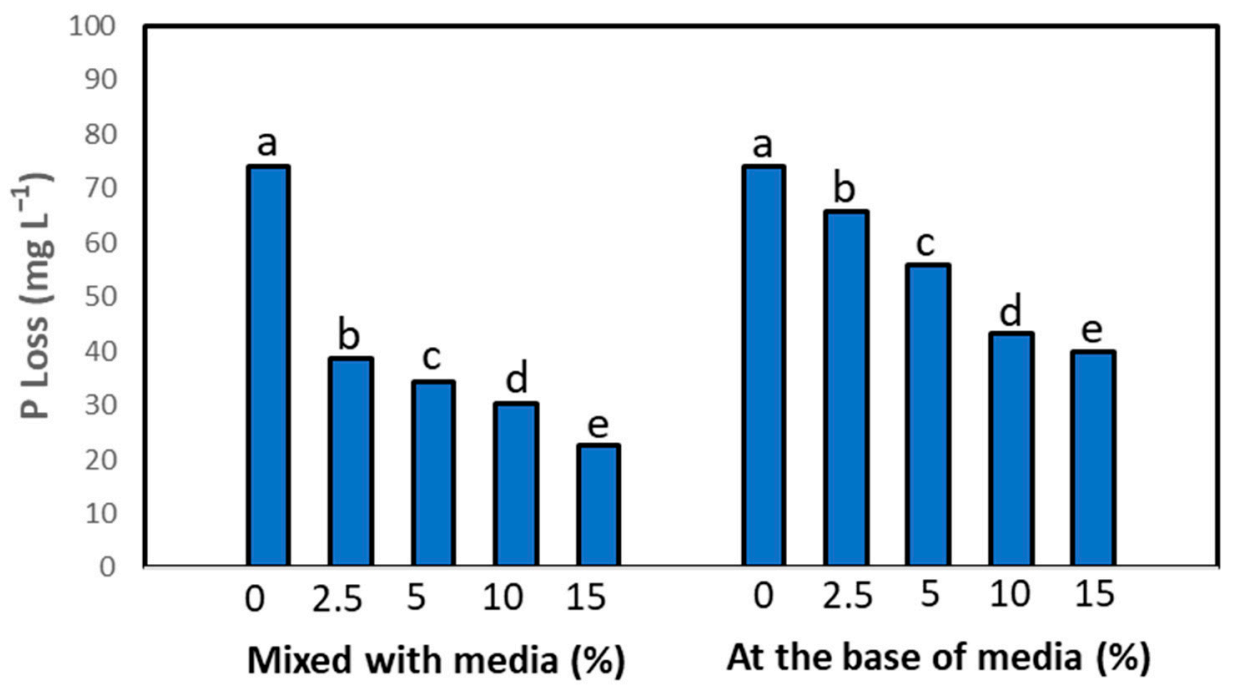

Figure 2. Mean dissolved reactive phosphorus (DRP) concentration loss in leachate as affected by FGD gypsum mixed with media or placed at the bottom of containers fertilized with a fast-release fertilizer. Within each gypsum application method, bars with the same letter are not significantly different $(p<0.05)$.

\section{Controlled-Release Fertilizer}

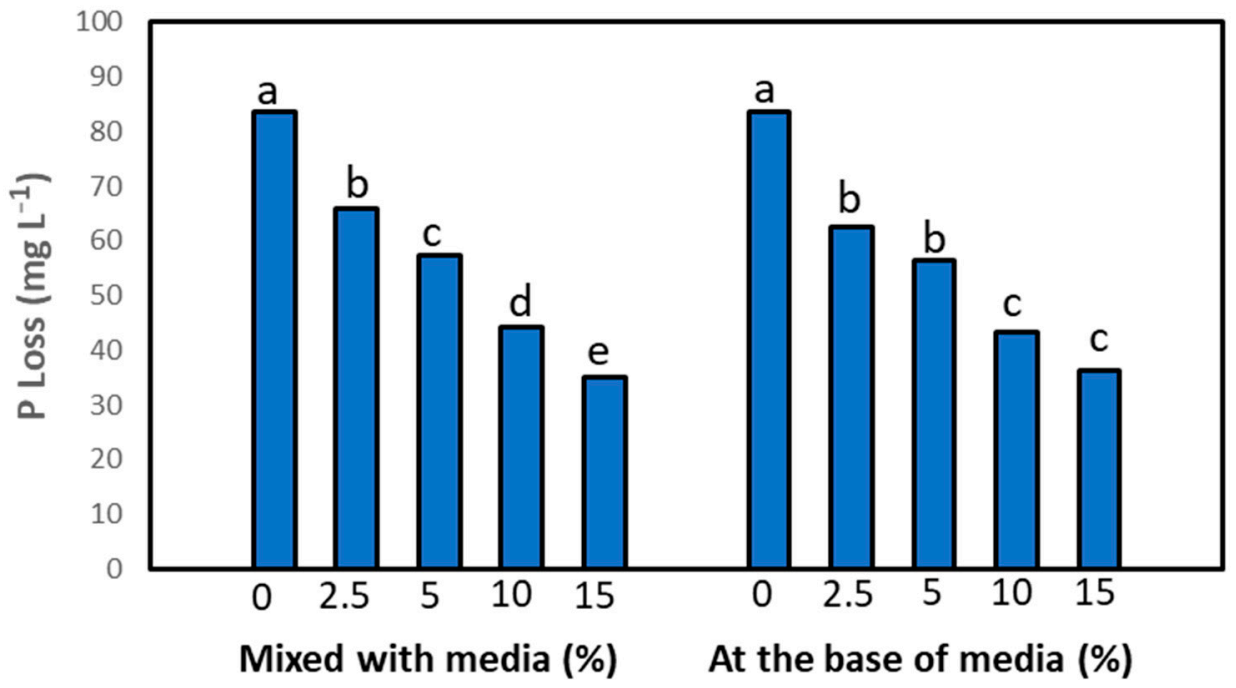

Figure 3. Mean dissolved reactive phosphorus (DRP) concentration loss in leachate as affected by FGD gypsum mixed with media or placed at the bottom of containers fertilized with a controlledrelease fertilizer. Within each gypsum application method, bars with the same letter are not significantly different $(p<0.05)$. 


\section{Fast-Released Fertilizer}

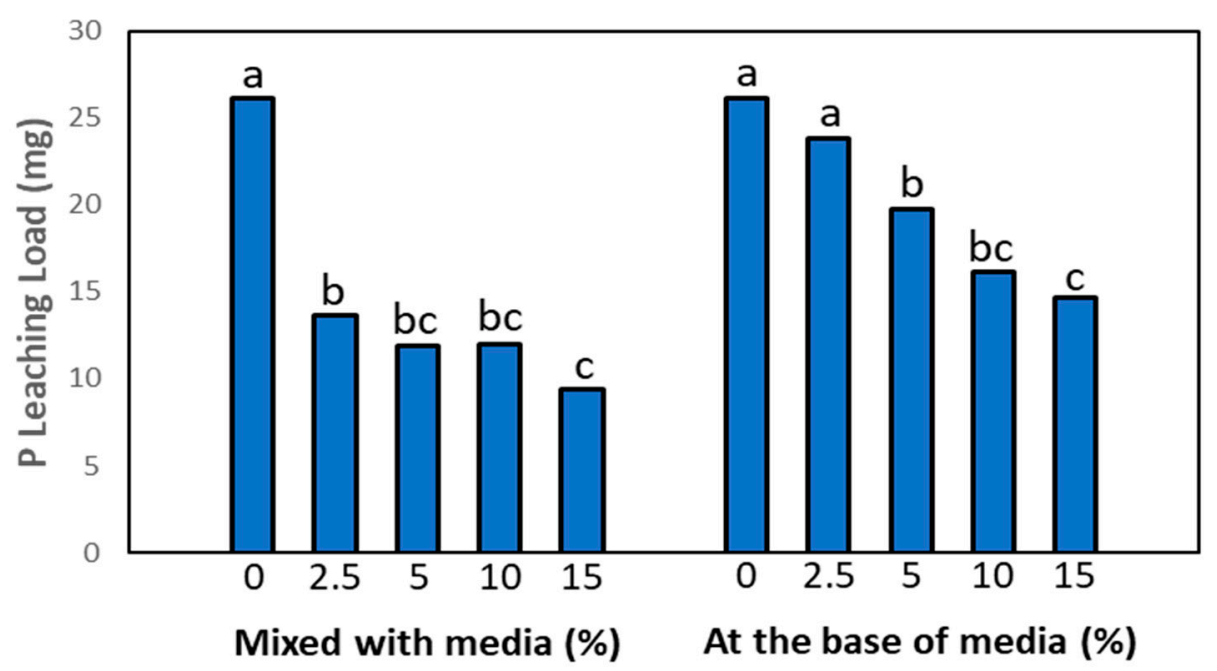

Figure 4. Mean dissolved reactive phosphorus (DRP) loading loss in leachate as affected by FGD gypsum mixed with media or placed at the bottom of containers fertilized with a fast-release fertilizer. Within each gypsum application method, bars with the same letter are not significantly different $(p<0.05)$.

\section{Controlled-Release Fertilizer}

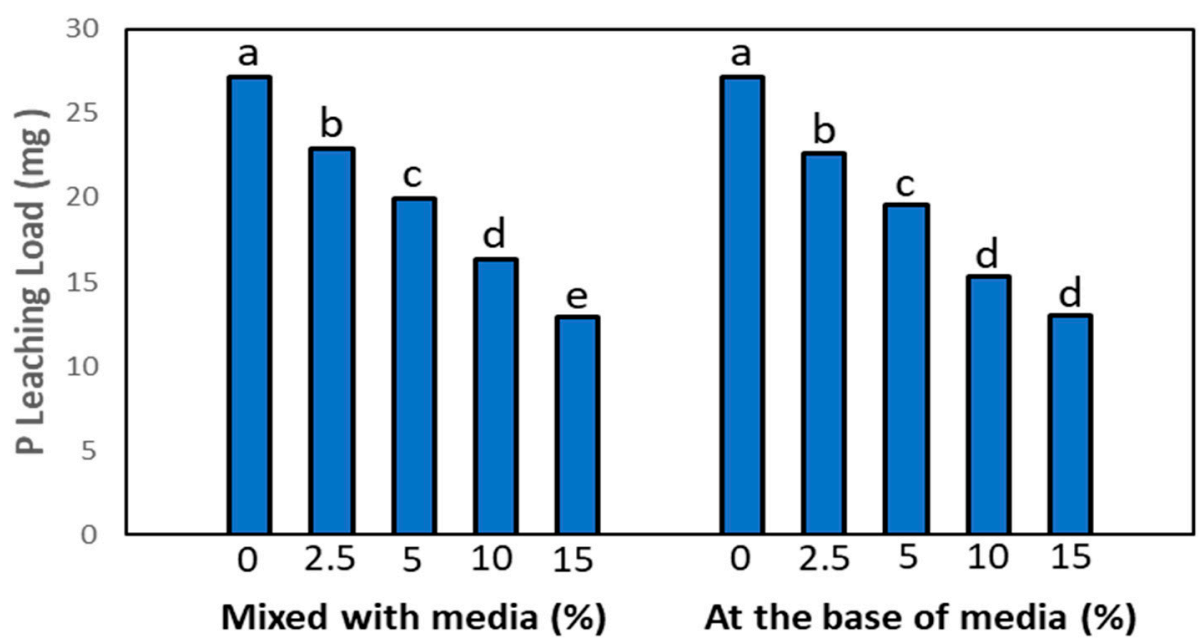

Figure 5. Mean dissolved reactive phosphorus (DRP) loading loss in leachate as affected by FGD gypsum mixed with media or placed at the bottom of containers fertilized with a con-trolled-release fertilizer. Within each gypsum application method, bars with the same letter are not significantly different $(p<0.05)$.

Findings from this study suggest that mixing FGD gypsum with growth media was more beneficial at reducing $\mathrm{P}$ loss than placing gypsum in a layer at the bottom of the container. One explanation for this is that when gypsum is placed at the base of container, it can only react with the soluble P during a leaching event. In other words, it intercepts the $\mathrm{P}$ in the leachate before it leaves container. On the other hand, when gypsum is mixed into the media it has a chance to interact with the soluble P while it is still in the media. Thus, it can be more effective at removing the $\mathrm{P}$ before it is even starting to move with the leachate water. As for the slow-release fertilizer, it is encased within a polymer coating. The polymer coating allows water to pass into the prill, allowing it to solubilize the fertilizer 
and then release the P slowly. Thus, the gypsum is in contact with the polymer coating rather than the fertilizer until it is available in the media.

From a production standpoint mixing, should be an easier and less expensive means of incorporating gypsum into containers. These preliminary data suggest that less gypsum may be needed to reduce $P$ loss from fast-release fertilizer; however, if controlled-release fertilizers are used, increasing the amount of gypsum will be beneficial in reducing P loss. These results require verification; further investigation is also needed in container systems with plants to determine the overall benefits that FGD gypsum may have on containerized crop production. It would also interesting to determine whether FGD gypsum can be used as a lime replacement.

\title{
4. Conclusions
}

Data from this study show that FGD gypsum can be used as a management tool to reduce DRP loss to leaching from horticultural potting media. Furthermore, reductions in $P$ loss were observed regardless of whether the FGD gypsum was mixed with the medium or placed at the bottom of the container. However, mixing the FGD gypsum was more effective at achieving $\mathrm{P}$ reductions when a fast-release fertilizer source was utilized. Phosphate concentrations in leachate decreased with increasing gypsum application rates up to $15 \%$ $(v / v)$. Reductions were observed throughout this study, indicating that FGD gypsum effectively reduced $P$ loss for at least 2 months. These results show that a producer could potentially reduce their environmental footprint by utilizing gypsum in containerized media. Future research should evaluate effects of higher rates of gypsum on P loss over longer timeframes from media potted with differing horticultural crops.

Author Contributions: Conceptualization, D.B.W. and H.A.T.; methodology, D.B.W., H.A.T., and G.B.R.; formal analysis, D.B.W. and G.B.R.; data curation, D.B.W.; writing-original draft preparation, D.B.W., H.A.T., and G.B.R.; writing-review and editing D.B.W., H.A.T., and G.B.R. All authors have read and agreed to the published version of the manuscript.

Funding: This research received no external funding.

Institutional Review Board Statement: Not applicable.

Informed Consent Statement: Not applicable.

Data Availability Statement: The datasets generated during and/or analyzed during the current study are available from the corresponding author on responsible request.

Acknowledgments: The authors acknowledge James Ashley Robinson and Gary Foster at the USDAARS National Soil Dynamics Laboratory for technical assistance in conducting the experiment and laboratory analyses.

Conflicts of Interest: The authors declare no conflict of interest.

\author{
Abbreviations \\ FGD—flue gas desulfurization; DRP—dissolved reactive phosphorus; ANOVA—analysis of variance.
}

\section{References}

1. US EPA. Safe and Sustainable Water Resources-Strategic Research Action Plan 2019-2022; EPA 601K20005; US Environmental Protection Agency: Washington, DC, USA, 2020. Available online: https://www.epa.gov/research/safe-and-sustainable-waterresources-strategic-research-action-plan-2019-2022 (accessed on 21 June 2021).

2. Sharpley, A.; Daniel, T.; Sims, T.; Lemunyon, J.L.; Stevens, R.; Parry, R. Agricultural Phosphorus and Eutrophication; United States Department of Agriculture: Washington, DC, USA, 2003.

3. Michaud, A.R.; Lauzier, R.; Laverdiere, M.R. Temporal and spatial variability in non-point source phosphorus in relation to agricultural production and terrestrial indicators: The Beaver Brook case study, Pike River basin, Quebec. In Lake Champlain: Partnership and Research in the New Millennium; Mihuc, T., Ed.; Kluwer Academic/Plenum Pub: Dordrecht, The Netherlands, 2004; pp. 97-121. 
4. Joosse, P.J.; Baker, D.B. Context for re-evaluating agricultural source phosphorus loadings to the great Lakes. Can. J. Soil Sci. 2011, 91,317-327. [CrossRef]

5. $\quad$ Bunting, L.; Leavitt, P.R.; Simpson, G.L.; Wissel, B.; Laird, K.R.; Cumming, B.F.; St Amand, A.; Engstrom, D.R. Increased variability and sudden ecosystem state change in Lake Winnipeg, Canada, caused by 20th century agriculture. Limnol. Oceanogr. 2016, 61, 2090-2107. [CrossRef]

6. US EPA. Nutrient Pollution: Sources and Solutions; US Environmental Protection Agency: Washington, DC, USA, 2017. Available online: https: / www.epa.gov/nutrientpollution/sources-and-solutions (accessed on 21 June 2021).

7. Boesch, D.F. Barriers and bridges in abating coastal Eutrophication. Front. Mar. Sci. 2019, 6, 123. [CrossRef]

8. USDA-NASS. 2019 Census of Horticultural Specialties. Volume 3, Special Studies, Part 3 AC-17-SS-3. 2020. Available online: https: //www.nass.usda.gov/Publications /AgCensus/2017/Online_Resources/Census_of_Horticulture_Specialties/HORTIC.pdf (accessed on 18 June 2021).

9. Scheiber, S.; Wang, Q.; Pearson, B.; Beeson, R.; Chen, J. Evaluation of irrigation frequency and quantity on leaf gas exchange, growth, and nitrate leaching of coleus in a simulated landscape. HortScience 2008, 43, 881-884. [CrossRef]

10. Bayer, A.; Whitaker, K.; Chappell, M.; Ruter, J.; van Iersel, M. Effect of irrigation duration and fertilizer rate on plant growth, substrate EC, and leaching volume. Acta Hortic. 2014, 1034, 477-484. [CrossRef]

11. Sanders, K.R.; Beasley JSBush, E.W.; Conger, S.L. Fertilizer source and irrigation depth affect nutrient leaching during coleus container production. J. Environ. Hortic. 2019, 37, 113-119. [CrossRef]

12. Weaver, D.; Summers, R. Soil factors influencing eutrophication. In Soilguide. A Handbook for Understanding and Managing Agricultural Soil; Moore, G., Ed.; Bulletin 4343; Department of Agriculture and Food: Perth, WA, Australia, 2001; pp. 243-250. Available online: https:/ / www.agric.wa.gov.au/sites/gateway / files/Soil\%20Guide\%20-\%20a\%20handbook.pdf (accessed on 21 June 2021).

13. Oh, Y.-M.; Nelson, P.V.; Hesterberg, D.L.; Niedziela, C.E. Efficacy of a phosphate-charged soil material in supplying phosphate for plant growth in soilless root media. Int. J. Agron. 2016, 10, doi. [CrossRef]

14. Williams, K.A.; Nelson, P.V. Low, controlled nutrient availability provided by organic waste materials for chrysanthemum. J. Am. Soc. Hortic. Sci. 1992, 117, 422-429. [CrossRef]

15. Ku, C.S.M.; Hershey, D.R. Growth response, nutrient leaching, and mass balance for potted poinsettia. II. Phosphorus. J. Am. Soc. Hortic. Sci. 1997, 122, 459-464. [CrossRef]

16. Norton, L.D. Gypsum soil amendment as a management practice in con-servation tillage to improve water quality. J. Soil Water Conserv. 2008, 63, 46A-48A. [CrossRef]

17. Watts, D.B.; Torbert, H.A. Impact of gypsum applied to buffer strips on reducing soluble P in surface water runoff. J. Environ. Qual. 2009, 38, 1511-1517. [CrossRef] [PubMed]

18. Endale, D.M.; Schomberg, H.H.; Fisher, D.S.; Franklin, D.H.; Jenkins, M.B. Flue gas desulfurization gypsum: Implication for runoff and nutrient losses associated with broiler litter use on pastures on Ultisols. J. Environ. Qual. 2014, 43, 281-289. [CrossRef]

19. Torbert, H.A.; Watts, D.B. Impact of flue gas desulfurization gyp-sum application on water quality in a Coastal Plain soil. J. Environ. Qual. 2014, 43, 273-280. [CrossRef]

20. Watts, D.B.; Torbert, H.A. Influence of flue gas desulfurization gypsum on reducing soluble phosphorus in successive runoff events from a coastal plain bermudagrass pasture. J. Environ. Qual. 2016, 45, 1071-1079. [CrossRef] [PubMed]

21. Watts, D.B.; Torbert, H.A. Three annual flue gas desulfurization gypsum applications on macronutrient and micronutrient losses in runoff from bermudagrass fertilized with poultry litter. Soil Sci. 2017, 182, 18-27. [CrossRef]

22. Watts, D.B.; Dick, W.A. Sustainable Uses of FGD gypsum in agricultural systems: Introduction. J. Environ. Qual. 2014, 43, 246-252. [CrossRef] [PubMed]

23. Chen, L.; Dick, W.A. Gypsum as an Agricultural Amendment: GENERAL Use Guidelines; Extension Bulletin 945; The Ohio State University: Columbus, OH, USA, 2011; Available online: https://fabe.osu.edu/sites/fabe/files/imce/files/Soybean/Gypsum\% 20Bulletin.pdf (accessed on 21 June 2021).

24. Watts, D.B.; Torbert, H.A.; Mitchell, C.C. Gypsum Use to Reduce P Loss from Agricultural Fields; Alabama Experiment Station: Auburn, AL, USA, 2013; Available online: https:/ / aurora.auburn.edu/handle/11200/44267 (accessed on 21 June 2021).

25. USDA-NRCS. Phosphorus Index for Alabama-A Planning Tool to Assess \& Manage P Movement. Agronomic Technical Note AL-72. 2014. Available online: https://efotg.sc.egov.usda.gov/references/public/AL/AGRON-AL-72_Phosphorus_Index.pdf (accessed on 21 June 2021).

26. USDA-NRCS. Amending Soil Properties with Gypsum Products. Conservation Practice Standard, Code 333. 2015. Available online: http:/ /www.nrcs.usda.gov/wps/portal/nrcs/detailfull/national/techni-cal/cp/ncps/?cid=nrcs143_026849 (accessed on 21 June 2021).

27. Kovar, J.L.; Pierzynski, G.M. Methods of Phosphorus Analysis for Soils, Sediments, Residuals, and Waters; Southern Cooperative Series Bull. 408; Virginia Tech University: Blacksburg, VA, USA, 2009; Available online: https:/ / sera17dotorg.files.wordpress.com/2015 /02/ sera-17-methods-for-p-2000.pdf (accessed on 21 June 2021).

28. SAS Institute. SAS/STAT for Windows. Release 9.4; SAS Institute: Cary, NC, USA, 2014.

29. Broschat, T.K. Rates of ammonium-nitrogen, nitrate-nitrogen, phosphorus, and potassium from two controlled-release fertilizers under different substrate environments. HortTechnology 2005, 15, 332-335. [CrossRef] 
30. Du, C.; Zhou, J.; Shaviv, A. Release characteristics of nutrients from polymer-coated compound controlled release fertilizers. J. Polym. Environ. 2006, 14, 223-230. [CrossRef]

31. Newman, J.P.; Albano, J.P.; Merhaut, D.J.; Blythe, E.K. Nutrient release from controlled-release fertilizers in a neutral-pH substrate in an outdoor environment: I. Leachate electrical conductivity, $\mathrm{pH}$, and nitrogen, phosphorus, and potassium concentrations. HortScience 2006, 41, 1674-1682. [CrossRef]

32. Broschat, T.K.; Moore, K.K. Release rates of ammonium-nitrogen, nitrate-nitrogen, phosphorus, potassium, magnesium, iron, and manganese from seven controlled-release fertilizers. Commun. Soil Sci. Plant Anal. 2007, 38, 843-850. [CrossRef]

33. Liu, G.; Zotarelli, L.; Li, Y.; Dinkins, D.; Wang, Q.; Ozores-Hampton, M. Controlled-Release and Slow-Release Fertilizers as Nutrient Management Tools; HS1255. UF/IFAS Extension; University of Florida: Gainesville, FL, USA, 2014; Available online: http: / / edis.ifas.ufl.edu/hs1255 (accessed on 21 June 2021).

34. Mikkelsen, R.L.; Williams, H.M.; Behel, A.D.J. Nitrogen leaching and plant uptake from controlled-released fertilizers. Fert. Res. 1994, 37, 43-50. [CrossRef]

35. Fernández-Escobar, R.; Benlloch, M.; Herrera, E.; García-Novelo, J.M. Effect of traditional and slow-release N fertilizers on growth of olive nursery plants and $\mathrm{N}$ losses by leaching. Sci. Hortic. 2004, 101, 39-49. [CrossRef]

36. Morgan, K.T.; Cushman, K.E.; Sato, S. Release mechanisms for slow- and controlled-release fertilizers and strategies for their use in vegetable production. HortTechnology 2009, 19, 10-12. [CrossRef]

37. Brauer, D.; Aiken, G.E.; Pote, D.H.; Livingston, S.J.; Norton, L.D.; Way, T.R.; Edwards, J.H. Amendments effects on soil test phosphorus. J. Environ. Qual. 2005, 34, 1682-1686. [CrossRef]

38. Lindsay, W.L. Chemical Equilibria in Soils; John Wiley \& Sons: New York, NY, USA, 1979.

39. Shreckhise, J.H.; Owen Jr, J.S.; Eick, M.J.; Niemiera, A.X.; Atland, J.E.; White, S.A. Dolomite and micronutrient fertilizer affect phosphorus fate in pine bark substrate used for containerized nursery crop production. Soil Sci. Soc. Am. J. 2019, 83, 1410-1420. [CrossRef]

40. King, K.W.; Williams, M.R.; Dick, W.A.; LaBarge, G.A. Decreasing phosphorus loss in tile-drained landscapes using flue gas desulfurization gypsum. J. Environ. Qual. 2016, 45, 1722-1730. [CrossRef]

41. Stout, W.L.; Sharpley, A.N.; Landa, J. Effectiveness of coal combustion by-products in controlling phosphorus export from soils. J. Environ. Qual. 2000, 29, 1239-1244. [CrossRef] 